\title{
Housing Vouchers and the Price of Rental Housing
}

\author{
BY MiCHAEL D. ERIKSEN AND AMANDA ROSS*
}

We estimate the effect of increasing the supply of housing vouchers on rents using a panel of housing units in the American Housing Survey. We do not find that an increase in vouchers affected the overall price of rental housing, but do estimate differences in effects based on an individual unit's rent before the voucher expansion. Our results are consistent with voucher recipients renting more expensive units after receiving the subsidy. We also find that the largest price increases were for units near the maximum allowable voucher rent in cities with an inelastic housing supply.

Keywords: Housing Policy; In-Kind Transfers; Vouchers

JEL classifications: H23, H42, I38, R31

The U.S. federal government provided over $\$ 50.2$ billion in housing assistance to low-income families in 2010 (U.S. OMB, 2011). Prior to 1974, the federal government relied almost exclusively on supply-side housing policies that constructed and operated housing units at below market rents. Since then, there has been a shift towards demand-side programs that provide vouchers to lowincome households that subsidize a portion of their housing rent to reside in privately-supplied units meeting minimum quality standards set by the federal government. Figure 1 illustrates that low-income housing subsidies have more than quadrupled since 1980, while outlays for low-income cash assistance

\footnotetext{
* Corresponding Author: Eriksen: Rawls College of Business, Texas Tech University, Lubbock, TX 79409 (email: mike.eriksen@ttu.edu); Ross: West Virginia University, Department of Economics, Morgantown, WV 26506 (email: amanda.ross@wvu.edu). We are grateful for comments on earlier versions of the manuscript from Ed Olsen, Gary Engelhardt, Stuart Rosenthal, Chris Cunningham, Amy Schwartz, Tami Gurley-Calvez, Jenny Schuetz, and seminar participants at University of Illinois: Urbana-Champaign, University of Florida, and Texas Tech University. All remaining errors are our own.
} 
programs have remained relatively constant. ${ }^{1}$ This increase roughly coincides with a change in low-income housing policy from supply- to demand-side housing subsidies.

Olsen (2003) provides a review of the advantages and disadvantages of different means-tested housing subsidies. For instance, previous research has shown that demand-side housing subsidies were generally more cost effective and resulted in a lower degree of concentrated poverty than supply-based subsidies. One potential negative consequence of demand-side housing subsidies is that they may increase the price of rental housing for unsubsidized households. This price increase would occur due to the subsidy increasing recipients' demand for eligible units without a sufficient supply response. In this paper, we draw upon a plausibly exogenous increase in the supply of housing vouchers to analyze how the increase affected the price of rental housing units 1 to 2 years after the expansion.

While a large social experiment in the 1970's found that vouchers had no statistically or economically significant impact on market rents, a more recent study by Susin (2002) reached a different conclusion. Using the first difference from 1974 to 1993, he estimates that the increased demand by voucher recipients since the program's inception increased the price of rental housing for unsubsidized households by 16 percent in the lowest average income neighborhoods. The results from that study suggest that the increase in rental prices associated with the allocation of housing vouchers resulted in a large net wealth transfer from unsubsidized, low-income households to private market landlords.

\footnotetext{
${ }^{1}$ Presented in Figure 1 are U.S. Office of Management and Budget (2011a) estimates of federal outlays for low-income cash and housing assistance between 1960 and 2010. Cash assistance programs included in this figure are the combined outlays associated with Temporary Assistance to Needy Families (TANF) and its predecessor Assistance to Families with Dependent Children (AFDC). Cash assistance in the figure does not include expenditures associated with Supplemental Security Insurance (SSI) or lost tax revenue from the Earned Income Tax Credit (EITC).
} 
One concern with Susin's results is that his estimates may be biased due to unobserved determinants of rent that were correlated with the existing supply of vouchers (Olsen, 2003). To address concerns about potential omitted variables, we construct a panel data series of rental units from the American Housing Survey (AHS) and estimate the effect of a relatively large increase in the supply of vouchers on rents of individual units. The increase in the number of vouchers between 2000 and 2002 represented one of the largest increases in a 3 year span since they were first allocated nationwide in the 1970's and resulted in significant variation between cities in the supply of vouchers (U.S. GAO, 2006). ${ }^{2}$ We draw upon this variation, individual unit fixed effects, and eligibility requirements to identify the short-term change in rents associated with expanding the supply of vouchers.

We do not find a statistically or economically meaningful impact of the increase in the supply of housing vouchers on overall rents. The maximum rent for a housing unit that is occupied by a voucher recipient is determined annually by the U.S. Department of Housing and Urban Development (HUD) and we also do not find a significant increase in rent for this subset of housing units after the expansion. We do, however, estimate significant differences in the effect of the additional vouchers based on an individual unit's rent relative to the maximum allowable rent before the voucher expansion. These estimated differences are consistent with voucher recipients increasing their demand for higher-quality units after receiving the subsidy, but decreasing their demand for lower-quality units they would have occupied without the subsidy.

\footnotetext{
${ }^{2}$ We measure the change in the supply of vouchers at the metropolitan level using announcements of awards by the U.S. Department of Housing and Urban Development in the Federal Register. We provide evidence that voucher allocations were not made in a manner that was systematically related to the past changes in rent and did not have a discernible effect on rents of ineligible units after the expansion.
} 
We also find evidence that the increase in the supply of vouchers had a different effect on the rents of individual units based on MSA-wide characteristics. Using MSA supply elasticity estimates provided in Saiz (2011), we find that the greatest positive price effect of the voucher expansion was on medium-quality units in MSAs near the maximum allowable rent in relatively supply inelastic cities (i.e., with an MSA supply elasticity estimated to be less than 1). In contrast, we estimate the greatest negative price effect on lowerquality units in MSAs with a relatively elastic housing supply. Our estimated price decrease in the supply elastic MSAs is consistent with a kinked-housing supply curve, popularized by Glaeser and Gyourko (2005), due to the durable nature of housing.

The rest of the paper proceeds as follows. We first describe the programmatic features of the housing voucher program, as well as provide a discussion of the underlying theoretical predictions and prior research. We then describe our empirical strategy, along with descriptions of our AHS sample and voucher expansions. We next present results of the effect of vouchers on rents in Section $\mathrm{V}$ and in Section VI consider how these effects vary based on the housing supply elasticity. The final section concludes with policy implications of the research.

\section{Background Information}

\section{A. Overview of the Housing Voucher Program}

Housing vouchers were first allocated nationwide through Section 8 of the U.S. Housing and Community Development Act of 1974. Prior to the use of vouchers, the federal government had relied on supply-side housing programs that located, constructed, and directly operated housing units with below-market rents for lowincome families. Housing vouchers were viewed as an attractive policy alternative 
to public housing since vouchers gave recipients the freedom to choose where to live given that the unit met minimum quality requirements. In addition, vouchers were considered to be more cost-effective, as they subsidized households to live in existing housing rather than constructing new housing units for that purpose (see Olsen (2003) for a review). The descendent of the original Section 8 voucher program was renamed Housing Choice Vouchers (HCV) in 1998 and is currently the largest rental housing assistance program in the U.S. The HCV program provided a subsidy to 2.2 million families in 2010 at an estimated cost of $\$ 18$ billion (OMB, 2011b).

A household is eligible to receive a housing voucher if its current income is less than 50 percent of the household size-adjusted median income in its metropolitan area. ${ }^{3}$ Unlike other social welfare programs, the supply of housing vouchers in a local area is fixed and there is excess demand for the subsidy by eligible households in almost all cities. In order to receive a housing voucher, an individual must apply through his or her local Public Housing Authority (PHA), which uses a waiting list to allocate the subsidy to eligible families. ${ }^{4}$ In most large cities, the waiting list to receive a voucher is so long that the applicants cannot be accommodated in a reasonable amount of time, so the local PHA may choose to not accept new applications temporarily (Olsen, 2003).

Once an individual is allocated a voucher, he or she has between 60 and 90 days to find an apartment appropriate for his or her household's size that meets the minimum quality guidelines as determined by HUD. The generosity of the subsidy is determined by the area's Fair Market Rent (FMR) for a unit with a similar number of bedrooms, as well as the household's current adjusted income.

\footnotetext{
${ }^{3}$ In addition, 75 percent of all housing vouchers must go to households with income less than or equal to 30 percent of the area size-adjusted median income. More information on voucher eligibility requirements is available at: http://portal.hud.gov/hudportal/HUD?src=/program_offices/public_indian_housing.

${ }^{4}$ See Olsen (2003) for a discussion of when certain populations may be moved to the top of the waiting list. Typical exceptions include the elderly, disabled, or homeless. Recipients who first received a voucher in 1998 waited on average 28 months to receive the subsidy after first applying (HUD, 1998).
} 
The FMR does not vary within an MSA and is approximately equal to the $40^{\text {th }}$ or $50^{\text {th }}$ percentile of estimated local housing rents as determined by HUD during the prior year. ${ }^{5}$

Figure 2 represents the budget set for new voucher recipients since 1998 where housing services $\left(Q_{H}\right)$ is measured on the horizontal axis and a composite good $\left(Q_{X}\right)$ is on the vertical axis. Similar to Olsen (2003), we assume a household's adjusted income $(Y)$ is given and they face a linear budget frontier subject to the market prices of housing $\left(P_{H}\right)$ and the composite good $\left(P_{X}\right)$. Unsubsidized households will consume some combination of $Q_{H}$ and $Q_{X}$ given the budget constraint

$$
Y=P_{H} Q_{H}+P_{X} Q_{X}
$$

In order to receive a subsidy, voucher recipients must consume a minimum quantity of housing services $\left(Q_{H}^{M I N}\right)$. So long as the household consumes that minimum of housing services, the federal government provides a payment to the landlord equal to the gap between the recipient's contribution of 30 percent of their household adjusted income and the market rent for that unit up to the FMR. The quantity of housing services able to be purchased with the FMR in a given local area is represented by $Q_{H}^{F M R}$ in Figure 2.

Voucher recipients, therefore, make the same contribution towards rent, 30 percent of their adjusted income, for housing services $Q_{H}^{M I N}$ through $Q_{H}^{F M R}$. Over this range, the generosity of the subsidy as a percentage share of their income would be the greatest if they consumed housing services corresponding to exactly the FMR, or

$$
\text { Max Subsidy }=P_{H} Q_{H}^{F M R}-0.3 Y
$$

\footnotetext{
${ }^{5}$ Individual PHAs may define their own voucher payment standard to be within 10 percent of the FMR threshold in their local area (McClure, 2005). See Collinson and Ganong (2013) for a more thorough description of how FMRs are calculated by HUD annually. For simplicity, we assume the payment standard to be the same as the FMR throughout the remainder of the paper, although in reality these may differ.
} 
Since 1998, voucher recipients may choose to rent a unit exceeding the FMR limit subject to contributing no more than 40 percent of their adjusted income towards rent, which we denote as $Q_{H}^{M A X}$ (McClure, 2005). However, the lump sum amount of the subsidy for recipients choosing to rent more expensive units would remain fixed at the amount in equation (2). Such households would be entirely responsible for the amount greater than the FMR.

In summary, the current voucher program provides incentives for recipients to adjust their housing consumption to be between $Q_{H}^{F M R}$ and $Q_{H}^{M A X}$ after receiving a subsidy. ${ }^{6}$ In the next section, we describe how increasing the supply of vouchers may theoretically affect the price of housing services.

\section{B. Theoretical Impact of Increasing the Supply of Vouchers}

While the additional housing vouchers will increase the demand for housing near the FMR threshold, the impact of the demand shift on the price of rental housing will ultimately depend on the price elasticity of supply. For example, if the supply of rental housing is perfectly elastic, then any changes in demand induced by additional housing vouchers would result in an adjustment in the quantity supplied of rental housing with minimal impacts on rents. However, if the price elasticity of supply is perfectly inelastic, then there will not be a quantity response when demand increases and the shift in the demand curve will create a sizable increase in price.

The existing research on the supply of rental housing suggests that there is an important temporal component in the supply response and that a great deal of heterogeneity exists between cities with regards to when that eventual response

\footnotetext{
${ }^{6}$ This result is consistent with Gubits et al (2006) that found voucher recipients significantly increase their total housing expenditures after receiving the subsidy. The maximum amount of housing services able to be purchased is subject to the restriction that the amount spent on housing cannot exceed 40 percent of an individual recipient's adjusted income and thus varies dramatically across and within metropolitan areas. Later in the paper, we show that $Q_{H}^{M A X}$ on average corresponds to 120 percent of the FMR limit for a 3-person household earning 50 percent of the median area income.
} 
occurs (see DiPasquale (1999) or Gyourko (2009) for reviews). Past research has found that the supply of housing is almost perfectly inelastic in the immediate term since it takes time to produce new units or modify existing units (Rosenthal, 1999). Over time, however, the response is more elastic depending on the supply of developable land and the presence of land-use regulations (Glaeser, Gyourko, \& Saks, 2008). Saiz (2011) developed a theoretical model and showed empirically that land-constrained cities are not only more expensive, but are also relatively more supply inelastic with respect to demand shocks. Depending on the supply of developable land and prices, he estimated the short- to intermediateterm supply elasticity for the average, population-weighted metropolitan area to be 1.75 , but range from a low of 0.60 in Miami, FL (inelastic) to a high of 5.45 in Wichita, KS (elastic). Based on these range in estimates, we anticipate significant heterogeneity between MSAs in the estimated effect of the increased demand created by voucher recipients on rental prices.

\section{Previous Research}

The Housing Assistance Supply Experiment (HASE) from the 1970s provided the first empirical evidence of whether housing vouchers increase the price the rental housing. HASE offered housing vouchers to all income-eligible applicants in Green Bay, Wisconsin and South Bend, Indiana and compared housing rents in these markets to similar cities without vouchers. Results from this field experiment did not find any significant differences in overall market rents between the two cities that received vouchers as compared to those that did not (Barnett, 1979; Struyk \& Bendick, 1981). ${ }^{7}$

\footnotetext{
${ }^{7}$ Researchers did, however, find that landlords in the two cities with vouchers were more likely to make repairs to existing units to meet the minimum quality standards of the program. See Struyk and Bendick (1981) for a review of the resulting research from HASE.
} 
Despite the strength of using data collected from a field experiment, there are concerns about the external validity of HASE, especially compared to the modern voucher program. The main difference is that the generosity of the housing subsidy offered through HASE was not conditional upon the actual housing expenditures of recipients, so HASE voucher recipients did not have the same incentives as modern voucher recipients to rent more expensive eligible units in their local area. Given the differences in program structure, we anticipate vouchers allocated under current program rules will have a greater effect on housing rent, especially for units near the maximum eligible amount. HASE was also conducted over 30 years ago in two moderately sized mid-western cities when vouchers were first allocated, so it is unclear if results obtained generalize to today's average housing market.

Susin (2002) revisited this question using national data from the AHS and found dramatically different results. To obtain his results, he first split the rental housing stock into terciles based on the neighborhood's average imputed income relative to its MSA in 1993, and then estimated separate hedonic regressions for each subset to create housing rent indices across MSA by income status. Using the rent indices he created, he then regressed the number of discretionary housing vouchers available per poor household in 1993 on his estimated change in rent between 1974, when vouchers were first allocated, and 1993. His results suggested that low-quality rental markets were quite supply inelastic and that the housing voucher program resulted in a 16 percent increase in rental prices for unsubsidized households in the lowest income neighborhoods.

While Susin's results are more externally valid to the modern voucher program, there is concern that omitted determinants of rent correlated with the past supply of voucher allocations may have biased his estimates (Khadduri \& Wilkins, 2007; Olsen, 2003; Schill \& Wachter, 2001). Olsen (2003) was 
particularly concerned with the comparison of the average rents in 1974 with those in 1993 in the lowest third of neighborhoods ranked by income, as the average quality of units changed significantly over that period. A related strand of research has estimated the effect of altering maximum rents associated with housing subsidies on the incidence of the program. Similar to Susin (2002), Laferrere \& Le Blanc (2004), Fack (2006), and Gibbons \& Manning (2006) found landlords capture a relatively large portion of the rental subsidy in France and the UK. Most recently, Collinson and Ganong (2013) use plausibly exogenous variation in FMRs induced by the 2000 Census to find that a $\$ 1$ increase in FMR rent resulted in approximately a \$0.13-0.20 increase in rents paid by vouchers recipients, although the portion of the increase due to actual increases in unit quality as a direct result of the increase were largely unobserved.

\section{Empirical Strategy}

To address the identification concerns discussed in the previous section, we create a panel data series of individual rental units from the American Housing Survey (AHS) from 1997 to 2003. To control for unobserved determinants of rental prices, we include a separate intercept, or fixed effect, for each individual housing unit in the panel. In regression form, we estimate

$$
R_{i t m}=\alpha_{i}+\beta V_{t m}+\theta X_{t m}+\gamma Z_{i t}+\delta_{t}+\varepsilon_{i t m},
$$

where $i$ indexes individual units, $t$ indexes survey year, and $m$ indexes the MSA the unit is located within. $R$ is the dependent variable and is the log of reported rent plus utilities, $V$ is the log of the supply of housing vouchers in the MSA where the unit is located in a given year, and $\varepsilon_{i t m}$ is an idiosyncratic, unit-specific error term. $X$ is a vector of observed time-varying determinants of rent at the MSA-level, $Z$ is a vector of observed time-varying determinants of rent at the unit 
level, and $\delta_{t}$ are year fixed effects to control for common unobserved determinants of rent. ${ }^{8}$ Given the presence of the individual unit fixed effects, $\alpha_{i}$, the coefficient $\beta$ represents the price elasticity of rental housing with respect to vouchers and will be identified using variation in the supply of vouchers across MSAs over time.

According to the U.S. Government Accountability Office (GAO, 2006), the supply of housing vouchers substantially increased between 1998 and 2002. This increase represented one of the largest increases in the supply of vouchers since the program's inception and is primarily explained by two separate allocation programs initiated by Congress. The first program was the Welfare-to-Work Housing Voucher Demonstration (WtWV) that allocated an additional 50,000 vouchers in 2000. The second was the Fair Share Voucher Allocation program that allocated an additional 154,605 vouchers between 2000 and 2002.

The two voucher allocation programs resulted in significant variation in the supply of housing vouchers at the MSA level. Table 1 presents information on the number of existing vouchers and the increase in housing vouchers per 1,000 units of existing rental stock for selected MSAs identified in the public-use version of the AHS. As evident in Table 1, there is a large degree of variation between MSAs in the number of vouchers that were awarded as a result of the two allocation programs. Fresno, CA received the largest increase with an additional 38.11 vouchers per 1,000 rental units, while 18 MSAs identified in the AHS received no vouchers through either program. The median increase was 4.51 additional vouchers per 1,000 rental units in Scranton, PA, and the inter-quartile range of the increase was 5.16 with Columbus, $\mathrm{OH}$ receiving 7.11 and Greenville, SC receiving 1.95 additional vouchers per 1,000 existing rental units.

\footnotetext{
${ }^{8}$ The time-variant MSA-level determinants of rent are the log of population, per capita income, and rental vacancy rates. The unit-specific determinants of rent that vary over time are reported evidence of rodents, presence of a washer or dryer, cracks in the walls larger than a dime, and if the sewer has backed up in the previous 2 years. We specified these unit-specific variables due to their availability in the AHS. Our estimates are not qualitatively sensitive to including up to 25 additional unit-specific attributes as controls as described later in the paper.
} 
We assume the voucher allocation process is exogenous to the anticipated twoyear change in rent of individual units within an MSA. ${ }^{9}$ In Table 2, we estimate which MSA attributes explain prior and future voucher allocations to the 134 MSAs identified in the public-use sample of the AHS. ${ }^{10}$ The dependent variable in column 1 is the stock of housing vouchers in each MSA as of 1999, while the dependent variable in column 2 is the percent change in housing vouchers between 2000 and 2002. While we find that more impoverished cities and those with a larger supply of renter-occupied housing units and located in the Northeastern U.S. were significantly more likely to have received housing vouchers prior to 1999 , we do not find any statistically significant variables that explain the change in vouchers between 2000 and 2002.

We also plot the percent increase in vouchers between 2000 and 2002 as a function of previous voucher allocations per existing rental housing in 1997 at the metropolitan level in Figure 3. As illustrated in the figure, the relationship between past and future voucher allocations is essentially flat with an estimated regression $\mathrm{R}^{2}$ less than 0.007 . We provide further evidence of the exogeneity of allocated vouchers to future rents by conducting a falsification test later in the paper.

\section{Data and Sample Characteristics}

The main dataset we draw upon is the national sample of the AHS. This survey is conducted every two years by the U.S. Census Bureau and is intended to be

\footnotetext{
${ }^{9}$ The Fair Share Vouchers were allocated as part of a two-step process where individual PHAs applied to HUD for vouchers set aside for each state based on 1990 Census attributes. PHAs also received favorable consideration for additional vouchers if they were considered to be well-run, based on criteria such as how many previous recipients had signed up for a federal savings program (U.S. Federal Register, 2002). The vouchers allocated under the WtWV were similarly competitive with individual PHAs receiving more vouchers based upon the strength of their application and the integration of the allocated vouchers with the other stated aims of the demonstration (Mills et. al., 2006).

${ }^{10}$ Each of the MSA attributes were measured as of 1999 with the exception of the number of rental housing units, which was obtained from the 2000 Decennial Census.
} 
nationally representative of all housing units in the U.S. We restrict our sample to the 8,388 rental housing units located in the 134 identified MSAs in the publicuse version of the AHS with a reported rent in 1997 and at least one other year between 1999 and 2003. ${ }^{11}$ We also exclude from our sample rental units indicated to be either publicly-owned (i.e., public housing) or to be rent restricted. The remaining sample includes 24,721 unique unit-by-survey year observations. The first two columns of Table 3 show the unweighted mean and standard deviation of the unit-specific characteristics of our sample. The third column of Table 3 shows the standard deviation of each of the variables after including separate unit and year fixed effects since this will be the variation used to identify our estimates. The average housing unit in our sample had a reported rent and utility costs of $\$ 1,013$ per month. ${ }^{12}$

Ideally, an annual time-series of housing vouchers would be available at the metropolitan level corresponding to the relatively large and plausibly exogenous increase in the supply of vouchers that occurred between 2000 and 2002. Unfortunately, HUD does not maintain a consistent time-series of voucher availability at the MSA-level on an annual basis prior to $2002 .^{13}$ To build our measure of voucher availability at the metropolitan level, we first determined the stock of existing housing vouchers prior to the voucher expansion in each metropolitan area using the 1997 Picture of Subsidized Households, which we assume remained unchanged between 1997 and 1999 (HUD, 1997). We established the number of additional housing vouchers available to be allocated in each metropolitan area between 2000 and 2002 using award announcements HUD

\footnotetext{
${ }^{11}$ Our MSAs are defined based on 1980 Decennial Census boundaries because the publicly available national sample of the AHS is only available using these definitions for confidentially reasons. We aggregate all reported MSA data series to this consistent level of geography throughout the analysis.

${ }^{12}$ All dollar values reported in the paper are in 2010 dollars based on the Consumer Price Index.

${ }^{13}$ Collinson and Ganong (2013) alternatively used HUD's PIC administrative database to calculate the effect on rent and quality of voucher recipients of increasing the FMR between 2002 and 2011. To our understanding there were no large and plausibly exogenous increases in the supply of housing vouchers during this time period, which we feel is essential to our empirical strategy.
} 
is required to publish in the Federal Register. The Federal Register is a daily publication of the Federal Government where HUD and other federal agencies post public announcements and funding awards. Using award announcements associated with the Fair Share and Welfare-to-Work allocation programs, we were able to determine the number of additional vouchers allocated to each public housing authority through each program. We then geocoded the mailing addresses of public housing authorities awarded additional vouchers to AHS-consistent metropolitan area boundaries to determine the increase in vouchers for each metropolitan area. ${ }^{14}$

The bottom part of Table 1 summarizes the number of vouchers awarded through each program for MSAs identified in the AHS. The Fair Share program resulted in 106,957 additional vouchers allocated in 116 of the 134 MSAs, while the WtWV program allocated an additional 29,603 vouchers to 54 MSAs. Combined, the two programs created an average increase of 18.2 percent in the supply of housing vouchers for the 134 MSAs identified in the public-use version of the AHS.

We supplemented these core data series with several other publicly available data sources. Annual population, per capita income and rental vacancy rates were obtained from the U.S. Census Bureau. ${ }^{15}$ Annual Fair Market Rents (FMRs) by bedroom size in each MSA were obtained from HUD. ${ }^{16}$ The average unit in our sample was located in an MSA that had a rental vacancy rate of 8

\footnotetext{
14 We implicitly assume no additional vouchers were allocated between 1997 and 1999 since we are interested in measuring the plausibly exogenous effect associated with the Fair Share and Welfare to Work voucher allocations. This assumption is supported by Weicher (2012), who showed that there were only small increases nationally in the number of new vouchers allocated between 1997 and 1999. The allocation mechanism and eventual location of those additional vouchers is unclear, so we were unable to incorporate them into our analysis. We also do not include vouchers allocated to State Housing Authorities in our sample as it is unclear where the eventual voucher recipients reside within each state. The vouchers allocated to state agencies represent a relatively small share of the total allocation associated with each program, less than 9 percent, and our understanding is that they were most often allocated to eligible households living in non-metropolitan areas not specifically served by a local housing authority.

${ }^{15}$ Annual population and per capita income estimates were obtained from Census' Small Area Income and Poverty Estimates data series and rental vacancy rates from their Housing Vacancies and Homeownership data series.

${ }^{16}$ Annual FMRs were downloaded from www.huduser.org/portal/datasets/fmr.
} 
percent and a population of 3.53 million. ${ }^{17}$ In addition, the average unit in our sample was located in an MSA with an average FMR for a two bedroom unit of $\$ 912.45$. Adjusted by bedroom size, the average reported rent plus utilities in our AHS sample was 113 percent of the respective FMR in the local metropolitan area where it was located.

\section{Impact of Vouchers on the Price of Rental Units}

The first column of Table 4 reports the elasticity of rents with respect to vouchers for all rental housing units in our sample. In addition to the listed MSA control variables in the table, the estimates also include unit-specific and year fixed effects and time-varying unit-specific attributes. ${ }^{18}$ Standard errors are clustered at the MSA level to allow for non-independence of idiosyncratic errors within MSAs and are reported in parentheses below each coefficient estimate.

As reported in Table 4, we do not find that units located in MSAs with larger increases in housing vouchers between 2000 and 2002 experienced statistically significant or economically meaningful differences in rents. Our point estimate of the elasticity is 0.007 for all rental units with a standard error of 0.015 . We estimate the elasticity of an individual unit's rent with respect to MSA per capita income to be 0.808 , population to be 0.360 , and rental vacancy rates to be -0.019 . Each of these estimated elasticities, with the exception of rental vacancy rates, is statistically significant at the 5 percent level.

The second column of Table 4 restricts our sample to the 4,337 units $(51.7$ percent of the total sample) with a rent that is less than 120 percent of the FMR in 1997. As discussed earlier in the paper, the generosity of the subsidy for voucher

\footnotetext{
${ }^{17}$ Note that our summary statistics are calculated at the unit level of our sample and not representative at the MSA level.

${ }^{18}$ The inclusion of the unit-specific and year fixed effects was supported through conducting a joint test of their significance.
} 
recipients is capped at approximately the FMR of their eligible unit-size in the MSA where they live. However, recipients are able to spend up to 40 percent of their adjusted income on more expensive units beyond the FMR limit given they are willing to pay the difference. These relaxed restrictions make units with rents below 120 percent of the FMR actually eligible to be occupied by voucher recipients. ${ }^{19}$ We therefore anticipate the effect of vouchers on rents to be greatest for this subset of units.

Although we estimate a marginally higher elasticity of 0.011 with respect to vouchers for these eligible units, our estimate is still not statistically different from 0 and is economically quite small. Given the average monthly rent for all units with a 1997 rent below 120 percent of the FMR was $\$ 770.11$, our estimate implies a 10 percent increase in the local supply of vouchers would coincide with a $\$ 0.80$ increase in monthly rent. Given the precision of the estimates, the 95 percent confidence interval of that estimate is also quite small and ranges from $\$ 1.12$ to $\$ 2.81$ per month.

The third and final column of Table 4 reports the estimated elasticity when the sample is restricted to the 4,051 units (48.3 percent of the sample) with a 1997 rent exceeding 120 percent of the FMR limit. Voucher recipients were unable to occupy these higher-priced units, so we do not anticipate that additional vouchers would have any significant effect on this segment of the market if the allocations were exogenous to anticipated changes in rent. We do not find a discernible effect of additional vouchers on rent for these units, further supporting the validity of the empirical model.

\footnotetext{
${ }^{19}$ We specified 120 percent of the FMR ratio as the initial cutoff for eligible units as we calculated this to be the average maximum rent allowable for a 3-person household earning exactly 50 percent of the adjusted median family income for the cities in our AHS sample. We relax this assumption later in the paper when calculating a polynomial function of the effect of additional vouchers based on the 1997 rent to FMR ratio.
} 
In addition to the elasticity estimates reported in Table 4, we used a variety of alternative specifications to test the sensitivity of our results. First, we defined eligible units as those within 200 percent, instead of 120 percent, of the FMR limit to restrict our sample in the middle column of Table 4. Second, we omitted housing units where a respondent reported that a housing voucher was used, as Susin (2002) argued these units should be omitted because their rents may be insulated against market forces. In both instances, we continued to estimate an economically small and statistically insignificant effect of increasing the supply of housing vouchers on the overall price of rental housing. As a final test of the robustness of the results, we included 25 additional unit-specific quality attributes available in the AHS as control variables. Despite reducing the sample size by more than 40 percent due to missing values for unit-specific attributes, our point estimates and statistical significance were almost identical to those reported in Table 4 .

\section{A. Unit Quality}

While we do not estimate an economically or statistically meaningful difference in rents for units in MSAs with larger increases in the supply of vouchers, we expect heterogeneity in the effects depending on the quality of the individual unit prior to the voucher expansion. We anticipate these differences will exist due to the subsidy structure encouraging recipients to vacate lower quality, and thus lower priced, rental housing and occupy units at or near the FMR limit in their respective MSA. If cross-price elasticities between the sub-markets are sufficiently low, we anticipate a price increase in units with rents near the FMR limit prior to the expansion, but a price decrease in units with a prior rent significantly below that amount. 
We provide evidence of the heterogeneity in effects based on unit quality using graphical and statistical techniques. We begin by modifying our previous estimation equation (3) to allow for heterogeneous effects based on how close the unit's price is to the FMR. We adjust the equation to include an interaction of the $\log$ of vouchers $(V)$ with a flexible $k^{\text {th }}$ order polynomial of the log of the ratio of the individual unit's rent in 1997 divided by the 1997 FMR, adjusted for bedroom size, in the MSA where that unit was located. This model is specified as

$$
R_{i t m}=\alpha_{i}+\sum_{j=0}^{k} B V_{t m}\left[R_{i, 1997} / F M R_{m, 1997}\right]^{j}+\theta X_{t m}+\gamma Z_{i t}+\delta_{t}+\varepsilon_{i t m},
$$

where $j$ denotes the order of the exponent of the interaction terms and $B$ is a vector of coefficients to be estimated using OLS. $R_{i, 1997}$ is the unit's rent in 1997 and $F M R_{m, 1997}$ is the size-adjusted FMR in the MSA where the unit is located. By interacting this ratio with the number of vouchers, we allow the voucher expansion to have a heterogeneous effect based on the proximity of that unit's rent to the FMR before the voucher expansion. ${ }^{20}$ The order of the polynomial was selected using Information Criterion suggested by Akaike based on the entropy maximization principle, which maximizes the fit on the model while penalizing the introduction of additional parameters.

Using these coefficients, we illustrate the marginal effect of the voucher expansion based on the individual unit's prior rent relative to the FMR limit in their MSA in Figure 4. The fit of the model was maximized using a $5^{\text {th }}$ order interacted polynomial with the supply of housing vouchers, although the general shape of the estimated effects was similar with even order polynomials. The solid line in Figure 4 represents the rental price elasticity from plotting the estimated $B$ 's, where the $\mathrm{x}$-axis is defined as the FMR ratio and the y-axis is the estimated rental price elasticity. The dashed lines represent the 90 percent confidence intervals of the interacted polynomial obtained using the delta-method. As ${ }^{20}$ To reduce the influence of outliers on the shape of the polynomial, we restrict the sample to units with a 1997 rent within
20 and 170 percent of the FMR, which includes approximately 90 percent of our sample. 
anticipated, we estimate significant differences in effects based on an individual unit's prior rent in 1997 before the voucher expansion. We find the greatest increase in rents for units within approximately 20 percent of the FMR threshold and a statistically significant decrease in price for units with a prior rent below 80 percent of that limit.

Next, we estimate if the heterogeneous effects that appear in the figure are statistically different using stratified regressions. These results are presented in Table 5. The first two columns of Table 5 stratify the sample based on whether a unit's rent was either below 80 percent or within 20 percent of the FMR limit in 1997. For units with a prior rent below 80 percent of the FMR, we estimate a negative elasticity of 0.095 , implying that a 10 percent increase in the supply of vouchers resulted in a 0.95 percent decrease in monthly rents. When we restrict the sample to medium-quality units with a 1997 rent within 20 percent of the FMR ratio, we estimate a positive elasticity of 0.038 . Since the average rent for units with a rent below 120 percent of the FMR was \$770.11, these estimates imply a 10 percent increase in the local supply of vouchers resulted in an average decrease of $\$ 7.32$ for lower-priced units, and $\$ 2.93$ increase in monthly rent for units within 20 percent of the FMR limit. ${ }^{21}$ Using standard errors clustered at the MSA-level, we find both of these effects are statistically distinct from 0 at the 5 percent level of significance. The third column of Table 5 pools the sample and uses an interaction term to test whether the coefficients are different from each other. The difference between the coefficients is statistically distinct from 0 at the 1 percent level of significance and is consistent with recipients occupying higherquality rental housing after receiving a subsidy.

\footnotetext{
${ }^{21}$ The average increase in the supply of vouchers as a result of the 2000 to 2002 voucher expansion was 18.2 percent, resulting in an average decrease from the expansion of $\$ 13.47$ for units with a previous rent less than 80 percent of the FMR before the voucher expansion and an average increase of $\$ 5.28$ for units with a previous rent within 20 percent of the FMR threshold.
} 


\section{B. Falsification Test to Check for Pre-Existing Trends}

An alternative explanation for the above patterns is that HUD may have differentially targeted vouchers to MSAs based on anticipated changes in rent. For example, HUD may have purposely allocated additional housing vouchers to MSAs where the rents of lower quality units were already decreasing. To determine whether such pre-existing trends occurred, we conducted a falsification test similar to Rothstein (2010) and Finkelstein (2002) by testing whether vouchers allocated between 2000 and 2002 had any predictive power on the change in rent between 1997 and 1999. In other words, we re-estimate equation (3) defining 1997 as the pre-voucher expansion period and act like additional vouchers awarded between 2000 and 2002 were instead allocated between 1997 and 1999. If pre-existing trends in rents were present, we would find a significant coefficient on the voucher variable, even though the increase in the voucher supply did not occur until after 1999.

The results of the falsification test are presented in Table 6 . In the first column, we show that future changes in housing vouchers had no explanatory effect on prior rents for all units less than 120 percent of the local FMR threshold. For these units, we estimate an economically small and statistically insignificant coefficient of -0.009 . In the second and third columns of Table 6, we stratify our sample based on whether units were within or below 20 percent of the FMR threshold in 1997. Whereas previously we estimated a significant difference in rents based on these cutoffs, we do not estimate a significant difference in rents from each other or 0 before the voucher expansion occurred. Overall, the results in Table 6 provide evidence that the voucher allocation process was not correlated with existing trends in rents. 


\section{Elasticity of Supply Results}

We also anticipate heterogeneity in effects based on the supply elasticity of the MSA where the additional vouchers were allocated. Economic theory suggests that the effect of vouchers on the price of rental housing should be the greatest in areas with a relatively less elastic housing supply. In areas where supply is more elastic, we anticipate changes in demand from allocating additional vouchers would induce a larger supply response, thus mitigating the positive effects on rents.

We again use a series of variables interacted with the local voucher supply to test if a heterogeneous effect on rents exists across MSAs based on supply elasticity. Our MSA supply elasticity estimates originate from Saiz (2011), who used Geographic Information Systems data to derive elasticity estimates for cities with a year 2000 population exceeding 500,000. ${ }^{22}$ Based on estimates reported in that paper, we were able to assign supply elasticities for 94 of the 134 MSAs geographically identified in the AHS.

Similar to the heterogeneous price effects based on prior rents presented in Figure 4, we interact the $\log$ of voucher supply at the local level with a $5^{\text {th }}$ order polynomial of the log of the MSA supply elasticity. ${ }^{23}$ The solid line in Figure 5 plots the estimated $B$ 's of the polynomial where the $\mathrm{x}$-axis is defined as the MSA supply elasticity and the dashed lines represent 90 percent confidence intervals of the $B$ estimates. Based on visually inspecting Figure 5, there was a positive price effects for individual units located in an MSA with an estimated supply elasticity less than 0.83 . We also estimate a negative and statistically significant price effect for units located in MSAs with an estimated supply elasticity greater than 1, which is indicative of a supply response in those areas.

\footnotetext{
${ }^{22}$ See Saiz (2011) for more details on how he created the MSA supply elasticity estimates.

${ }^{23}$ Similar to our unit-quality estimates, we restrict the sample to rental units with a 1997 rent between 20 and 170 percent of the FMR to reduce the influence of outliers on the polynomial shape.
} 
The first column of Table 7 reports the elasticity of rent with respect to vouchers for the subset of units located in an MSA with a supply elasticity reported by Saiz (2011) and a 1997 rent less than 120 percent of the FMR limit. As before, we do not find an economic or statistically significant effect of additional vouchers on these units. In the second column of Table 7, we introduce an interaction term of the supply of vouchers in the MSA with an indicator that equals one if Saiz estimated the supply elasticity in that MSA to be greater than or equal to 1 (i.e., supply elastic). The coefficient on the interaction term can be interpreted as the difference in the estimated elasticities, with the coefficient on the $\log$ of vouchers now interpreted as the elasticity of rent with respect to vouchers in supply inelastic areas (i.e., an estimated supply elasticity less than 1). Based on the coefficients with the interaction term, we estimate the average marginal effect to be 0.113 for units in cities with an estimated supply elasticity that is less than 1 , and -0.077 for units in more supply elastic areas.

In the final column of Table 7, we include interactions of the supply of housing vouchers with both the indicator that the estimated elasticity of supply of the MSA is greater than one and the indicator that a unit's rent divided by the FMR before the voucher expansion is less than 80 percent to test if one effect dominates. $^{24}$ We find the coefficient on both interaction terms to be negative and significantly different from 0 at the 5 percent level of significance. In Table 8 we calculate the estimated linear combination of coefficients on the interaction terms reported in the last column of Table 7. Based on those coefficient estimates, we find that the positive effect of vouchers is the greatest in relatively supply inelastic cities (i.e., with a supply elasticity less than 1) and the negative effect is the greatest in relatively supply elastic areas. Both estimated elasticities are sizeable in economic terms and statistically different from 0 at the 5 percent level

\footnotetext{
${ }^{24}$ We also include an interaction of each interaction, although do not find a significant difference in rents for these subset
} of units. 
of significance. In dollar terms, the estimates suggest a 10 percent increase in vouchers resulted in a $\$ 17.87$ increase and a $\$ 22.87$ decrease in monthly rent for each category of unit. ${ }^{25}$

The exact reason why rents decrease the most for lower-quality units in supply elastic areas is unknown and warrants future research. One explanation is that suppliers are more likely able to construct new medium-quality units to meet increased demand by recent voucher recipients. Although this explanation is speculative, it would be consistent with the kinked-supply curve popularized by Glaeser and Gyourko (2005) due to the durable nature of housing.

\section{Summary and Policy Implications}

In this study, we do not find that additional housing vouchers increased the overall price of rental housing. This finding is in contrast to earlier research that found housing vouchers significantly increased the price of low-quality rental housing to the detriment of unsubsidized renters, but these earlier findings may have been biased due to unobserved determinants of rent. We addressed concerns about omitted variable bias confounding previous research by constructing a panel of individual rental housing units observed in multiple waves of the AHS before and after a relatively large expansion in the supply of housing vouchers.

While we do not detect a discernible overall effect of housing vouchers on the change in rents, we do find important differences in estimated effects based on the individual unit's rent in 1997 before the voucher expansion. Based on a unit's 1997 rent relative the maximum allowable rent under the program in their local

\footnotetext{
${ }^{25} \mathrm{We}$ also considered the effect of the regulatory environment by interacting the supply of vouchers with the Wharton Residential Land-Use Regulatory Index developed by Gyourko, Saiz, and Summers (2008). We estimate a positive and statistically significant price elasticity for medium-quality units near the FMR limit with respect to vouchers for units in cities with a regulatory index value greater than 0 . We prefer the MSA supply elasticity estimates of Saiz (2011) due to the possible endogenous reasons such regulations could originate, but the results are available from the authors upon request.
} 
area prior to the voucher expansion, we estimate a 10 percent increase in vouchers resulted in a 0.39 percent increase in the price of rental housing for units with a rent within 20 percent of the local Fair Market Rent in 1997. We also estimate a 10 percent increase in vouchers resulted in a 0.95 percent decrease in rent for lower-quality units with a 1997 rent less than 80 percent FMR. Considering average rents, our results imply that the 18.2 percent nationwide increase in the supply of vouchers that occurred between 2000 and 2002 resulted in an average increase in monthly rents of $\$ 5.28$ for medium-quality units near the FMR threshold and an average decrease in monthly rents of $\$ 13.47$ for lower-quality units. These results are consistent with the subsidy structure encouraging recipients to vacate lower quality units to occupy higher quality units after receiving the subsidy. We also find that the increase in rents was the highest for units in MSAs with an estimated supply elasticity less than 1, although it is unclear if having an inelastic housing supply is also correlated with other unobserved MSA attributes.

It is also important to recognize that we estimate a short-term effect particular to a specific expansion in vouchers between 2000 and 2002. Although we have no reason to suspect our results are not externally valid towards other voucher expansions, the long-term effects of increasing the supply of vouchers on rents are unclear. We hope researchers will investigate these issues in the future given the importance of the topic.

Our results suggest that additional research is needed on how best to target housing subsidies in the future. Currently, the majority of federal housing subsidies are allocated to cities based on per capita measures to ensure an equal distribution across the country, with little regard to which policies may work best based upon the characteristics of the local housing market. We have shown in this paper that relatively small increases in rents do occur for units near the maximum 
allowable rent when additional housing vouchers are allocated, but were virtually non-existent in cities with an elastic housing supply 1 to 2 years after the vouchers were allocated. We have not shown whether similar differences in effects occur based on local attributes for supply-based subsidies, although economic theory suggests crowd out and other negative effects on private market suppliers would be the least in areas with a relatively inelastic housing supply. Future research should investigate this issue further and attempt to identify other local factors policy makers should take into account when targeting housing subsidies in the future.

\section{REFERENCES}

Barnett, C. Lance, 1979. "Expected and Actual Effects of Housing Allowances on Housing Prices," Journal of the American Real Estate and Urban Economics Association 7(3): 277-297.

Collinson, Robert A. and Peter Ganong, 2013. "Incidence and Price Discrimination: Evidence from Housing Vouchers." Available at SSRN: http://ssrn.com/abstract-2255799. June 9, 2013.

DiPasquale, Denise, 1999. "Why Don't We Know More about Housing Supply?" Journal of Real Estate Finance and Economics 18: 9-23.

Fack, Gabrielle, 2006. "Are Housing Benefits an Effective Way to Redistribute Income? Evidence from a Natural Experiment in France." Labour Economics, 13(6): 747-771.

Finkelstein, Amy, 2002. "The Effect of Tax Subsidies to Employer-Provided Supplementary Health Insurance: Evidence from Canada." Journal of Public Economics, 84: 305-339.

Gibbons, Stephen and Alan Manning, 2006. "The Incidence of UK Housing Benefit: Evidence from the 1990s Reforms." Journal of Public Economics, 90(45): 799-822.

Glaeser, Edward L. and Joseph Gyourko, 2005. "Urban Decline and Durable Housing." Journal of Political Economy, 113(2): 345-375. 
Glaeser, Edward L., Joseph Gyourko, and Raven E. Saks, 2006. "Urban Growth and Housing Supply.” Journal of Economic Geography, 6(1): 71-89.

Gyourko, Joseph, Albert Saiz, and Anita Summers, 2008. "A New Measure of the Local Regulatory Environment for Housing Markets: The Wharton Residential Land Use Regulatory Index." Urban Studies 45(3): 693-729.

Gyourko, Joseph, 2009. "Housing Supply." Annual Review of Economics, 1(1): 295-318.

Government Accountability Office (U.S. GAO), 2006. "Rental Housing Assistance: Policy Decisions and Market Factors Explain Changes in the Costs of the Section 8 Programs," Report to the Subcommittee on Housing and Community Opportunity, House of Representatives, US Congress.

Gubits, Daniel B., Larry L. Orr, Gregory B. Mills, Michelle L. Wood, Bulbul Kaul, David A. Long, and Judith D. Feins, 2007. The Impact of Housing Choice Vouchers on Employment, Earnings and Mean-Tested Benefits. Cambridge, MA.

Gubits, Daniel B., Jill Khadduri, and Jennifer Turnham, 2009. Housing Patterns of Low Income Families with Children: Further Analysis of Data from the Study of the Effects of Housing Vouchers on Welfare Families. Cambridge, MA.

Khadduri, Jill and Charles Wilkens, 2007. "Designing Subsidized Rental Housing Programs: What have we Learned?" Joint Center of Housing Studies Working Paper.

LaFerrere, Anne and David Le Blanc, 2004. "'How do Housing Allowances Affect Rents? An Empirical Analysis of the French Case." Journal of Housing Economics 13: 36-67.

Mayer, Susan E. and Christopher Jencks, 1989. "Poverty and the Distribution of Material Hardship.” Journal of Human Resources 24: 88-114.

McClure, Kurt, 2005. "Rent Burden in the Housing Choice Voucher Program." Citysape 8(2): 5-20.

McMillian, Robert, 2005. "Competition, Incentive, and Public School Productivity." Journal of Public Economics, 89(5-6): 1133-1154.

Mills, G., D.B. Gubits, L. Orr, D. Long, J. Feins, B. Kaul, M. Wood, A. Jones and Associates, Cloudburst Consulting, and the QED Group, 2006. Effects of Housing Vouchers on Welfare Families: Final Report. Prepared for the U.S. Department of Housing and Urban Development, Office of Policy Development and Research. Cambridge, MA: Abt Associates Inc. 
Olsen, Edgar, 2003. "Housing Programs for Low-Income Households," in Robert A. Moffitt (ed.) Means-Tested Transfer Programs in the United States (Chicago: University of Chicago Press): 365-441.

Rothstein, Jesse, 2010. "Teach Quality in Educational Production: Tracking, Decay, and Student Achievement." The Quarterly Journal of Economics, 125(1): 175-214.

Rosenthal, Stuart, 1999. "Residential Buildings and the Cost of New Construction: New Evidence on the Efficiency of the Housing Market" Review of Economics and Statistics 81(2): 288-302.

Saiz, Albert, 2011. "The Geographic Determinants of Housing Supply." Quarterly Journal of Economics 125(3): 1253-1296.

Schill, Michael H. and Susan M. Wachter, 2001. "Principles to Guide Housing Policy at the Beginning of the Millennium." Cityscape 5(2): 5-19.

Struyk, R. and M. Bendick, 1981. Housing Vouchers for the Poor. Washington, DC: The Urban Institute Press.

Susin, Scott, 2002. "Rent Vouchers and the Price of Low-Income Housing." Journal of Public Economics 83: 109-152.

U.S. Federal Register, 2002. Fair Share Allocation of Incremental Voucher

Funding, Fiscal Year 2002. Available at:

http://archives.hud.gov/funding/2002/nofa02/other/fsnofa.txt.

U.S. Department of Housing and Urban Development (HUD), 1997 A Picture of Subsidized Households. Available at: http://www.huduser.org/portal/datasets/assthsg/statedata97/index.html.

U.S. Office of Management and Budget (OMB), 2011a. Outlays for Discretionary Programs: 1962-2017. Available at: http://www.whitehouse.gov/omb/budget/Historicals

U.S. Office of Management and Budget (OMB), 2011b. Budget of the U.S. Federal Government. Available at: http://www.whitehouse.gov/sites/default/files/omb/budget/fy2011/

Weicher, John C., 2012. Housing Policy at a Crossroads: The Why, How, and Who of Assistance Programs. The AEI Press, Washington, DC. 


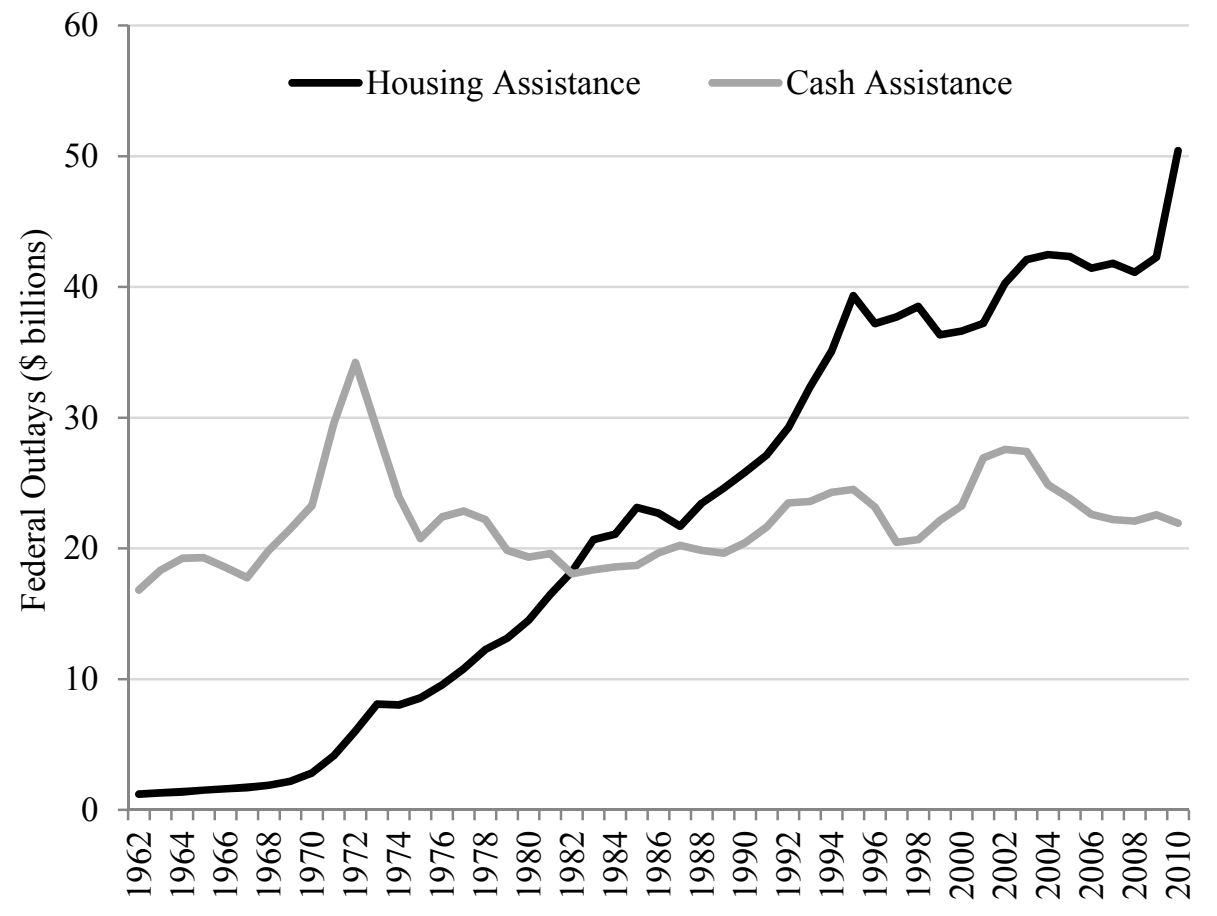

FigURE 1. FEDERAL OUTLAYS FOR LOW-INCOME HOUSING AND CASH ASSISTANCE PROGRAMS

Notes: Outlays reported by the U.S. Office of Management \& Budget (2011) represented in 2010 dollars, deflated using Consumer Price Index. Low-income cash assistance includes outlays associated with Temporary Assistance for Needy Families (TANF) and Aid to Families with Dependent Children (AFDC). 


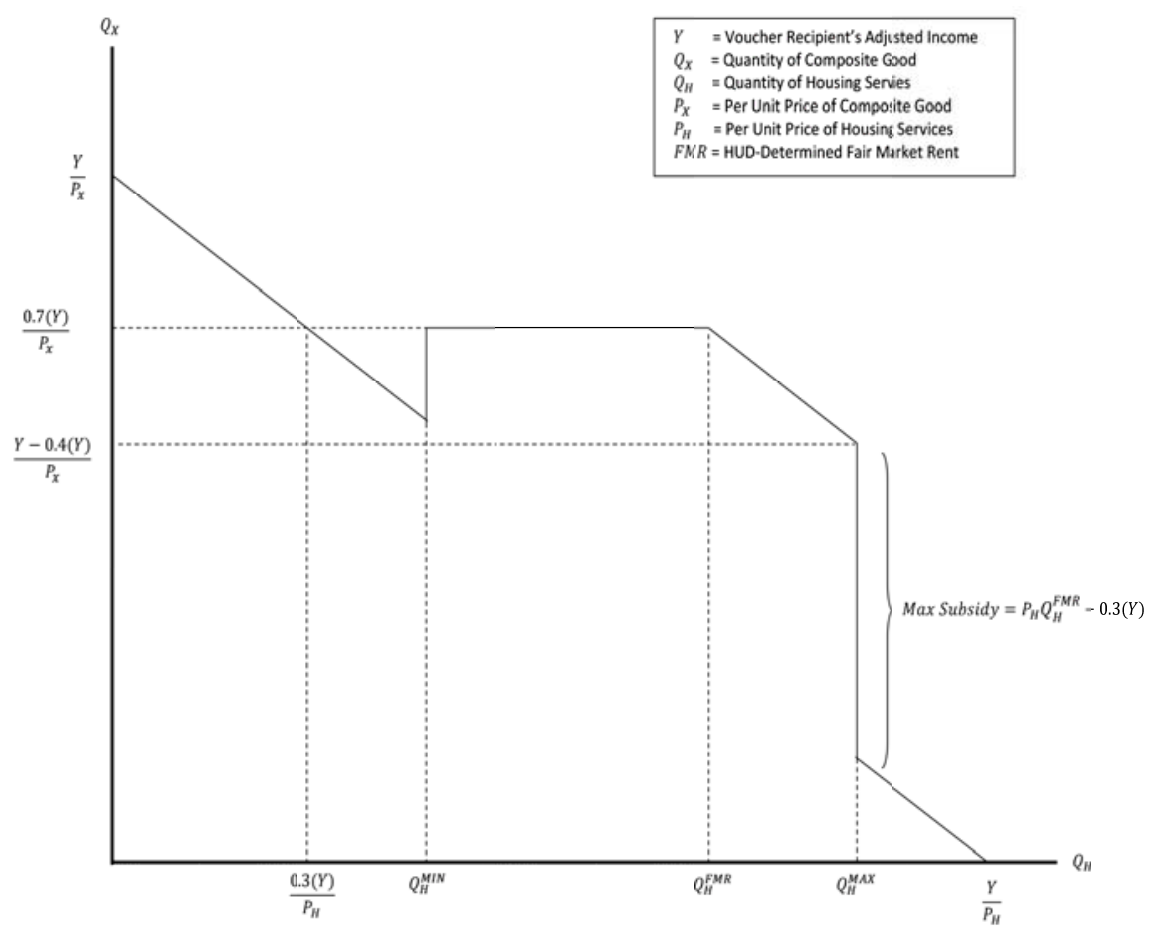

Figure 2. Budget SET OF Housing Voucher Recipients 


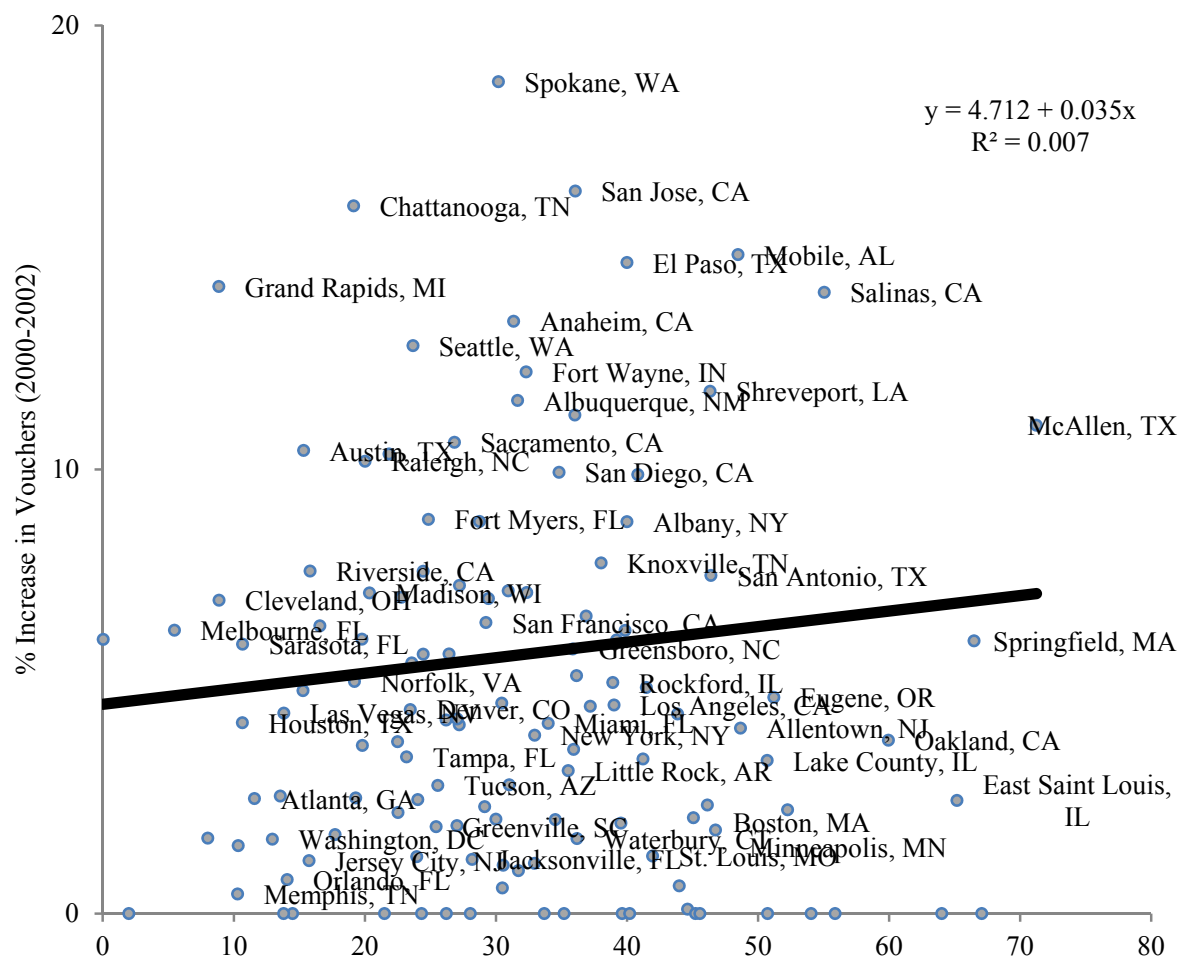

Number of Vouchers Per 1,000 Rental Housing Units in 1997

FigURE 3. RELATIONSHIP BETWEEN VOUCHER AVAILABILITY PER EXISTING RENTAL Housing IN 1997 AND Future Voucher Allocations

Notes: The figure represents a scatterplot of the percent increase in new vouchers allocated between 2000 and 2002 to each MSA as a function of the number of previously allocated vouchers per 1,000 rental housing units as of 1997 . The solid line represents the intercept and slope of the relationship estimated using ordinary least squares. Outliers included in the regression, but excluded in the figure due to greater than 20 percent increase in allocated vouchers are: Stockton, CA, East Lansing, MI, Vallejo, CA, and Fresno, CA. 


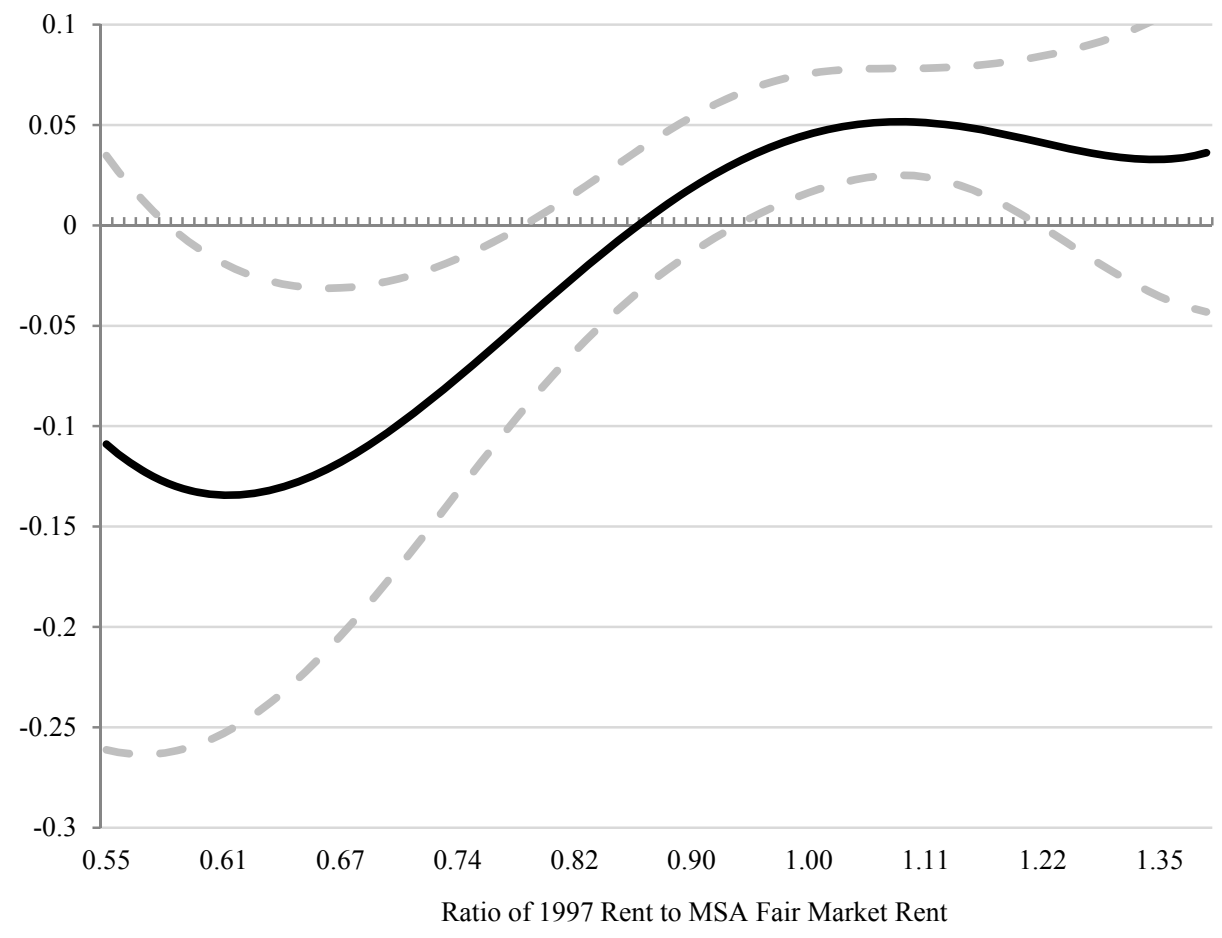

Figure 4. Elasticity of ReNTAL PRice With ResPeCt to Vouchers BY RATIO OF 1997 RENT DIVIDED BY MSA FAIR MARKET RENT

Notes: Authors' calculations from interacting the supply of vouchers with 5th order polynomial of an individual unit's rent before the voucher expansion in 1997 to the Fair Market Rent for a unit of similar size in its MSA according to HUD. Dashed lines represent 90 percent confidence intervals. 


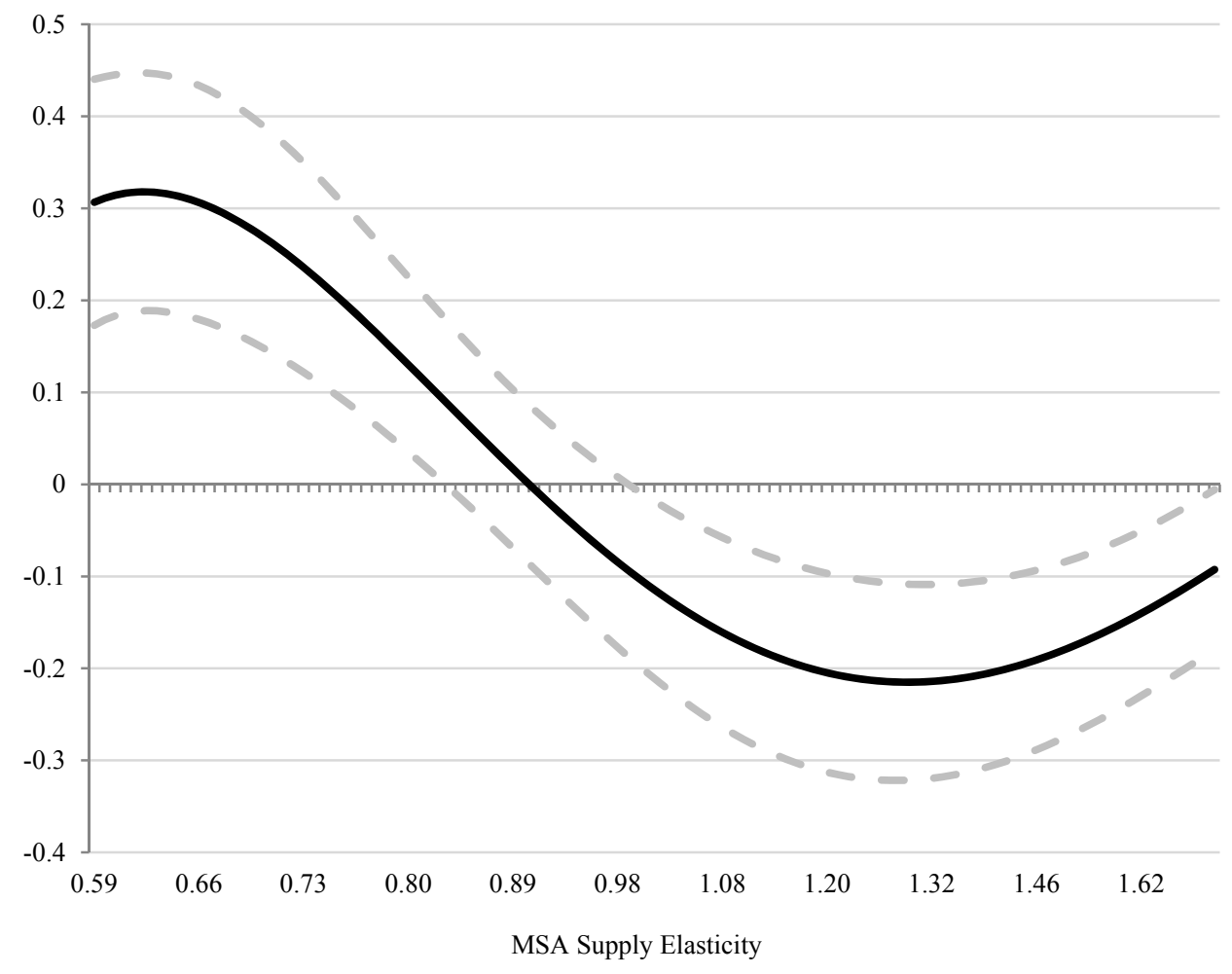

Figure 5. Elasticity OF RENTAL PRICE

WITH RESPECT TO VOUCHERS BY MSA SUPPLY ELASTICITY

Notes: Authors' calculations from interacting vouchers with a 5th order polynomial MSA supply elasticity estimates created by Saiz (2011). Dashed lines represent 90 percent confidence intervals. 
TABLE 1. INCREASE IN HOUSING VouChers By RANK FOR SELECTED MSAs, 2000-2002

\begin{tabular}{|c|c|c|c|c|c|}
\hline \multirow{2}{*}{ Rank } & \multirow{2}{*}{ Metropolitan Area } & \multirow{2}{*}{$\begin{array}{c}\text { \# of } \\
\text { Vouchers in } \\
1997\end{array}$} & \multicolumn{3}{|c|}{ Additional Vouchers ('00-'02) } \\
\hline & & & $\begin{array}{l}\text { Fair Share } \\
\text { Allocation }\end{array}$ & $\begin{array}{l}\text { Welfare-to- } \\
\text { Work }\end{array}$ & $\begin{array}{l}\text { Per } 1,000 \\
\text { Rental Units }\end{array}$ \\
\hline 1 & Fresno, CA & 4,792 & 3,069 & 1,400 & 38.11 \\
\hline 2 & Augusta, GA & 2,172 & 699 & 865 & 27.65 \\
\hline 3 & Santa Barbara, CA & 3,737 & 1,385 & 0 & 22.44 \\
\hline 4 & Vallejo, CA & 3,527 & 769 & 639 & 22.20 \\
\hline 5 & Stockton, CA & 2,733 & 929 & 700 & 21.71 \\
\hline 32 & Riverside, CA & 5,908 & 2,881 & 0 & 7.71 \\
\hline 33 & Columbus, $\mathrm{OH}$ & 5,760 & 1,816 & 0 & 7.71 \\
\hline 34 & San Antonio, TX & 10,161 & 1,668 & 0 & 7.62 \\
\hline 65 & Denver, $\mathrm{CO}$ & 6,811 & 1,134 & 200 & 4.60 \\
\hline 66 & Las Vegas, NV & 3,205 & 347 & 700 & 4.51 \\
\hline 67 & Scranton, PA & 3,201 & 328 & 0 & 4.49 \\
\hline 68 & Chicago, IL & 27,313 & 3,477 & 950 & 4.38 \\
\hline 98 & Daytona, FL & 1,339 & 98 & 0 & 1.98 \\
\hline 99 & Greenville, SC & 2,460 & 189 & 0 & 1.95 \\
\hline 100 & Minneapolis, MN & 14,672 & 395 & 195 & 1.88 \\
\hline 113 & Orlando, FL & 2,956 & 161 & 0 & 0.77 \\
\hline 114 & Utica, NY & 1,829 & 26 & 0 & 0.63 \\
\hline 115 & Kansas City, MO & 6,933 & 131 & 0 & 0.58 \\
\hline 116 & Memphis, TN & 1,627 & 70 & 0 & 0.44 \\
\hline 117 & Hartford, CT & 6,335 & 14 & 0 & 0.10 \\
\hline \multicolumn{2}{|c|}{ Total in AHS Sample } & 751,765 & 106,957 & 29,603 & 22.85 \\
\hline
\end{tabular}

Notes: The table indicates the number of existing and additional housing vouchers allocated through the Fair Share Allocation and Welfare to Work programs between 2000 and 2002. The table is sorted by rank of additional vouchers allocated as a share of existing rental housing per 1,000 units measured in the 2000 Decennial Census. The public-use version of the American Housing Survey (AHS) identifies 134 unique metropolitan statistical areas, of which 18 received no additional vouchers through either program. 
TABle 2. MSA DEterminants of PASt AND Future Housing Voucher Allocations

\begin{tabular}{|c|c|c|}
\hline & $\begin{array}{l}\text { Previously Allocated } \\
\text { Vouchers as of } 1999\end{array}$ & $\begin{array}{c}\text { Percent Change in } \\
\text { Vouchers Between } 2000 \\
\text { and } 2002\end{array}$ \\
\hline \multirow{2}{*}{ Log of MSA Population (1999) } & 0.187 & 0.409 \\
\hline & $(0.461)$ & $(2.938)$ \\
\hline \multirow[t]{2}{*}{ Log of Renter-Occupied Units (2000) } & $0.808^{*}$ & -6.127 \\
\hline & $(0.444)$ & $(6.546)$ \\
\hline \multirow[t]{2}{*}{ Log of MSA Per Capita Income (1999) } & 0.247 & -2.064 \\
\hline & $(0.598)$ & $(3.971)$ \\
\hline \multirow[t]{2}{*}{ Log Fair Market Rent (1999) } & 0.109 & -1.173 \\
\hline & $(0.112)$ & $(1.419)$ \\
\hline \multirow{2}{*}{ Log of Vacancy Rate (1999) } & 0.008 & -4.336 \\
\hline & $(0.236)$ & $(4.415)$ \\
\hline \multirow[t]{2}{*}{ Log of MSA Poverty Rate (1999) } & 0.354 & 6.519 \\
\hline & $(0.410)$ & $(6.880)$ \\
\hline \multirow[t]{2}{*}{ Log of Voucher Eligible Individuals (1999) } & $-0.351^{*}$ & -1.826 \\
\hline & $(0.202)$ & $(2.222)$ \\
\hline \multirow[t]{2}{*}{ MSA Located in Northeastern Census Region } & $0.322 * *$ & -0.806 \\
\hline & $(0.148)$ & $(0.961)$ \\
\hline \multirow[t]{2}{*}{ MSA Located in Western Census Region } & -0.024 & 4.165 \\
\hline & $(0.221)$ & $(4.156)$ \\
\hline \multirow[t]{2}{*}{ MSA Located in Southern Census Region } & -0.074 & -0.405 \\
\hline & $(0.168)$ & $(0.818)$ \\
\hline$R^{2}$ & 0.606 & 0.057 \\
\hline Observations (MSAs) & 134 & 134 \\
\hline \multicolumn{3}{|c|}{$\begin{array}{l}\text { Notes: The table shows the coefficients of MSA-level regressions where the dependent variable in } \\
\text { column } 1 \text { is defined as the number of allocated vouchers as of } 1999 \text { and the dependent variable in } \\
\text { column } 2 \text { is defined as the percentage increase in housing vouchers between } 2000 \text { and } 2002 \text { due to the } \\
\text { Fair Share and Welfare-to-Work Voucher Allocation Programs. The independent variables in each } \\
\text { column are measured as of } 1999 \text {, with the exception of renter-occupied units that were measured from } \\
\text { the } 2000 \text { Decennial Census. Robust standard errors are in parentheses and asterisks indicate statistical } \\
\text { significance at the following levels: } * \mathrm{p}<0.1,{ }^{* *} \mathrm{p}<0.05,{ }^{* * *} \mathrm{p}<0.01 \text {. }\end{array}$} \\
\hline
\end{tabular}


Table 3. Descriptive Statistics for American Housing Survey (AHS) SAmPle

\begin{tabular}{|c|c|c|c|}
\hline & Mean & Standard Deviation & $\begin{array}{l}\text { Standard Deviation } \\
\text { Net of Unit and Year } \\
\text { Fixed Effects }\end{array}$ \\
\hline \multicolumn{4}{|l|}{ Unit Attributes } \\
\hline Monthly Rent plus Utilities & $1,013.43$ & 558.69 & 271.24 \\
\hline Monthly Rent as Percent of FMR & 1.13 & 0.52 & 0.29 \\
\hline Evidence of Rodents & 0.14 & 0.34 & 0.24 \\
\hline Presence of Washer or Dryer & 0.39 & 0.49 & 0.20 \\
\hline Large Cracks in Wall & 0.08 & 0.27 & 0.20 \\
\hline Recent Sewage Problems & 0.02 & 0.14 & 0.11 \\
\hline \multicolumn{4}{|l|}{ MSA Attributes } \\
\hline Housing Vouchers & $20,498.82$ & $24,935.43$ & $1,185.31$ \\
\hline Rental Vacancy Rate & 0.08 & 0.03 & 0.01 \\
\hline Population $(1,000$ 's) & $3,653.26$ & $3,125.65$ & 79.98 \\
\hline Per Capita Income (1,000's) & 39.41 & 6.49 & 0.77 \\
\hline Monthly Fair Market Rent & 912.45 & 288.62 & 79.56 \\
\hline \multicolumn{4}{|l|}{ Census Regions } \\
\hline Northeast & 0.20 & 0.40 & . \\
\hline South & 0.28 & 0.45 & . \\
\hline Midwest & 0.22 & 0.41 & . \\
\hline West & 0.30 & 0.46 & . \\
\hline \# of Units & 8,388 & & . \\
\hline MSAs & 134 & . & . \\
\hline
\end{tabular}

Notes: The sample is restricted to rental units in the American Housing Survey (AHS) between 1997, 1999, 2001, and 2003 as described in the text. FMR indicates the 1997 Fair Market Rent as determined by the Department of Housing and Urban Development for a 2 bedroom unit. The third column indicates the standard deviation of each of the variables after separately differencing unit and year fixed effects. See text for additional sample restrictions and descriptions of variables. All summary measures are based on the unweighted average of all rental units in the sample. 
TABLE 4. ElASTICITY OF HOUSING RENTS WiTH RESPECT TO HOUSING VOUCHERS

\begin{tabular}{|c|c|c|c|}
\hline & \multirow[b]{2}{*}{ Full Sample } & \multicolumn{2}{|c|}{$\begin{array}{c}\text { Ratio of } 1997 \text { Rent Divided by } \\
\text { HUD Fair Market Rent }\end{array}$} \\
\hline & & Ratio $<120 \%$ & Ratio $\geq 120 \%$ \\
\hline \multirow[t]{2}{*}{ Log of Vouchers } & 0.007 & 0.011 & -0.002 \\
\hline & $(0.015)$ & $(0.013)$ & $(0.025)$ \\
\hline \multirow[t]{2}{*}{ Log of MSA Per Capita Income } & $0.808 * * *$ & $0.872 * * *$ & $0.874 * * *$ \\
\hline & $(0.209)$ & $(0.209)$ & $(0.278)$ \\
\hline \multirow[t]{2}{*}{ Log of MSA Population } & $0.359 * *$ & $0.343^{*}$ & $0.458 * *$ \\
\hline & $(0.175)$ & $(0.194)$ & $(0.202)$ \\
\hline \multirow[t]{2}{*}{ Log of Vacancy Rate } & -0.019 & -0.010 & 0.019 \\
\hline & $(0.020)$ & $(0.019)$ & $(0.030)$ \\
\hline Unit Fixed Effects & 8,388 & 4,337 & 4,051 \\
\hline Year Fixed Effects & 4 & 4 & 4 \\
\hline Within $R^{2}$ & 0.094 & 0.172 & 0.044 \\
\hline Observations & 24,721 & 14,029 & 10,692 \\
\hline \multicolumn{4}{|c|}{$\begin{array}{l}\text { Notes: The table indicates the coefficients of panel regressions where the dependent variable is defined } \\
\text { as the log of monthly housing rent plus utilities between } 1997 \text { and } 2003 \text {. The first column reports results } \\
\text { for the unrestricted AHS sample. The second and third column report estimates where the AHS sample is } \\
\text { stratified based on the individual unit's rent in } 1997 \text { divided by the U.S. Department of Housing and } \\
\text { Urban Development (HUD) Fair Market Rent (FMR) in 1997, adjusted for bedroom size, in the MSA } \\
\text { where the unit is located. Each set of regressions includes individual unit and year fixed effects and unit- } \\
\text { specific controls for: evidence of rodents, presence of washer or dryer, large cracks in the wall, and if the } \\
\text { sewage system broke down in the last two years. Robust standard errors clustered at the MSA level are in } \\
\text { parentheses and asterisks indicate statistical significance at the following levels: } * \mathrm{p}<0.1,{ }^{* *} \mathrm{p}<0.05 \text {, } \\
* * * \mathrm{p}<0.01 \text {. }\end{array}$} \\
\hline
\end{tabular}


TABLe 5. Heterogeneous EFFects of Vouchers on Housing ReNTS by Ratio of 1997 Rent Divided BY HUD FAIR MARKET RENT BEFORE THE VOUCHER EXPANSION

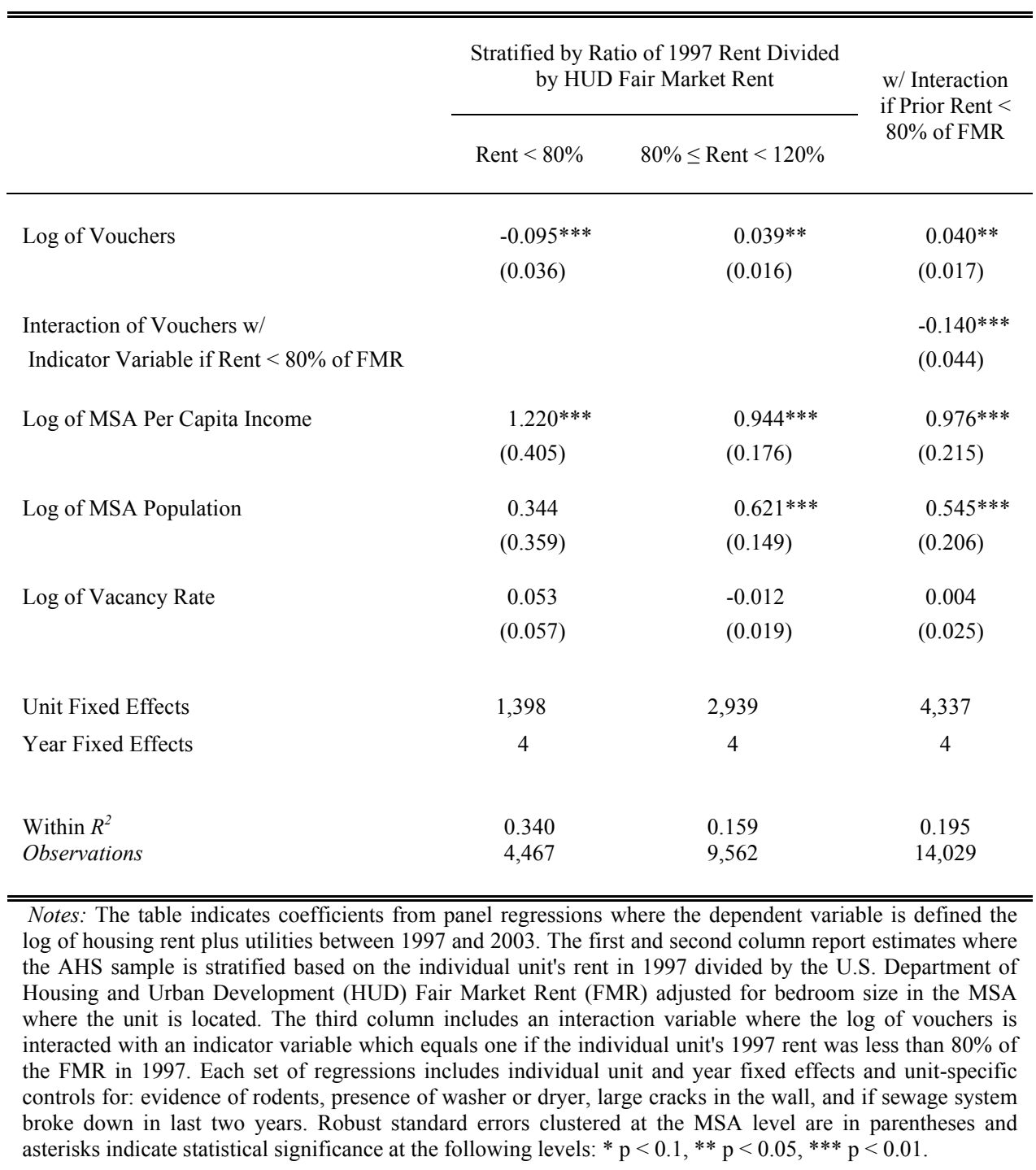


TABle 6. FAlsifiCATION TEST to CHECK FOR PRE-EXISTING TRENDS IN RENT By SPECIFying CHANGE IN HOUSING VOUCHERS INSTEAD OCCURRED BETWEEN 1997 AND 1999.

\begin{tabular}{|c|c|c|c|}
\hline & \multicolumn{3}{|c|}{ Ratio of 1997 Rent Divided by HUD Fair Market Rent } \\
\hline & Rent $<120 \%$ & Rent $<80 \%$ & $80 \% \leq$ Rent $<120 \%$ \\
\hline \multirow{2}{*}{$\begin{array}{l}\% \text { Change in Future } \\
\text { Vouchers }\end{array}$} & 0.009 & -0.022 & 0.004 \\
\hline & $(0.019)$ & $(0.110)$ & $(0.014)$ \\
\hline Unit Fixed Effects & 2,362 & 712 & 1,650 \\
\hline Observations & 4,724 & 1,424 & 3,300 \\
\hline
\end{tabular}

Notes. The first column reports results for the unrestricted AHS sample. The second and third columns report estimates where the AHS sample is stratified based on the individual unit's rent in 1997 divided by the US Department of Housing and Urban Development (HUD) Fair Market Rent (FMR) in 1997, adjusted for bedroom size, in the MSA where the unit is located. Standard errors clustered at the MSA level are reported in parentheses and indicate significance at the following levels: ${ }^{*} \mathrm{p}<0.1,{ }^{* *} \mathrm{p}<0.05, * * * \mathrm{p}<0.01$. 
TABLE 7. HeterogeneOUS EFFECTS OF VOUCHERS ON RENTS By MSA SUPPly ElASTiCITY

\begin{tabular}{|c|c|c|c|}
\hline & No Interaction & $\begin{array}{l}\text { w/ MSA } \\
\text { Supply } \\
\text { Interaction }\end{array}$ & $\begin{array}{l}\text { w/ MSA Supply } \\
\text { \& Ratio of Prior } \\
\text { Rent Interaction }\end{array}$ \\
\hline Log of Vouchers & $\begin{array}{c}0.023 \\
(0.057)\end{array}$ & $\begin{array}{l}0.113^{*} \\
(0.064)\end{array}$ & $\begin{array}{l}0.232 * * * \\
(0.056)\end{array}$ \\
\hline $\begin{array}{l}\text { Interaction of Vouchers w/ } \\
\text { Indicator Variable if Supply Elasticity } \geq 1\end{array}$ & & $\begin{array}{l}-0.190 * * \\
(0.091)\end{array}$ & $\begin{array}{l}-0.254 * * * \\
(0.086)\end{array}$ \\
\hline $\begin{array}{l}\text { Interaction of Vouchers } w / \\
\text { Indicator Variable if Rent }<80 \% \text { of FMR }\end{array}$ & & & $\begin{array}{l}-0.279 * * \\
(0.126)\end{array}$ \\
\hline $\begin{array}{l}\text { Interaction of Vouchers w/ } \\
\text { Indicator Variable if Supply Elasticity } \geq 1 \& \\
\text { Indicator Variable if Rent }<80 \% \text { of FMR }\end{array}$ & & & $\begin{array}{c}0.004 \\
(0.007)\end{array}$ \\
\hline Unit Fixed Effects & 3,973 & 3,973 & 3,973 \\
\hline Year Fixed Effects & 4 & 4 & 4 \\
\hline $\begin{array}{l}\text { Within } R^{2} \\
\text { Observations }\end{array}$ & $\begin{array}{c}0.177 \\
12,861\end{array}$ & $\begin{array}{c}0.177 \\
12,861\end{array}$ & $\begin{array}{c}0.204 \\
12,861\end{array}$ \\
\hline
\end{tabular}

Notes: The table indicates coefficients from panel regressions where the dependent variable is defined as the log of housing rent plus utilities between 1997 and 2003. The sample is restricted to 3,974 housing units with a 1997 housing rent less than 120 percent of the FMR limit and with an estimated housing supply elasticity reported by Saiz (2011). Estimates reported in the first column include no interaction term. Estimates in the second column include an interaction of the log of housing vouchers with an indicator variable that equals one if the estimated supply elasticity in the MSA where the unit is located is greater than or equal to 1 . Estimates in the third column income an interaction of the supply elasticity indicator and an indicator for if the ratio of the unit's 1997 rent divided by the FMR is less than 80 percent of the FMR indicator. Each set of regressions includes individual unit and year fixed effects, MSA specific controls (log of population, income, and rental vacancy) and unit-specific controls (evidence of rodents, presence of washer or dryer, large cracks in the wall, and if sewage system broke down in last two years). Robust standard errors clustered at the MSA level are in parentheses and asterisks indicate statistical significance at the following levels: ${ }^{*} \mathrm{p}<0.1,{ }^{* *} \mathrm{p}<0.05,{ }^{* * *} \mathrm{p}<0.01$. 
TABLE 8. SUMmARY OF HETEROGENEOUS EFFECTS OF VOUCHERS ON HOUSING RENT BASED FROM INTERACTIONS OF SUPPLY ELASTICITY AND PRIOR RENT BEFORE THE VOUCHER EXPANSION

\begin{tabular}{|c|c|c|c|}
\hline \multirow{4}{*}{ 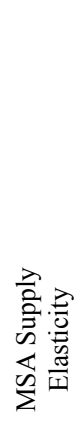 } & \multirow[b]{3}{*}{$<1$} & \multicolumn{2}{|c|}{$\begin{array}{c}\text { Stratified by Ratio of Prior Rent in } 1997 \text { Divided by } \\
\text { HUD Fair Market Rent }\end{array}$} \\
\hline & & Rent $<80 \%$ & $80 \% \leq$ Rent $<120 \%$ \\
\hline & & $\begin{array}{l}-0.046 \\
(0.143)\end{array}$ & $\begin{array}{l}0.232 * * * \\
(0.056)\end{array}$ \\
\hline & $\geq 1$ & $\begin{array}{l}-0.297 * * \\
(0.132)\end{array}$ & $\begin{array}{l}-0.022 \\
(0.074)\end{array}$ \\
\hline
\end{tabular}

Notes: The table indicates the linear combination of the interacted coefficients reported in Table 7. Robust standard errors clustered at the MSA level of the combined estimates are in parentheses and asterisks indicate statistical significance at the following levels: ${ }^{*} \mathrm{p}<0.1,{ }^{* *} \mathrm{p}<$ $0.05, * * * \mathrm{p}<0.01$. 